\title{
THE EFFECT OF AUTHENTIC READING MATERIAL TO ENHANCE STUDENTS' READING COMPREHENSION
}

\author{
Asri Nofa Rama \\ English Education Study Program, Teacher Training and Educational Faculty, \\ Lakidende University \\ e-mail: asrirama21@gmail.com
}

\begin{abstract}
This study aimed to find out the extent to which authentic material enhance students' reading comprehension. This study used quasi-experimental design that consists of experimental class and control class. In experimental class referred to the class that is given authentic material. While the control class referred to the class that is given the usual set of conditions or textbook. The study was carried out at Lakidende University of Unaaha and Sembilan belas November University with 60 undergraduates as the sample. Data were collected by using reading test. Moreover, the data were analyzed quantitatively and interpreted by using the software program of SPSS 24.0. This study found that Authentic reading material give a significant effect on students' reading comprehension from pre-test to post-test revealed the significant difference $(0.001<$ 0.05) before and after the implementation of Authentic reading material.
\end{abstract}

Keywords: Authentic Reading Material, Reading Comprehension. 


\section{INTRODUCTION}

In the last decades, many researchers have been carried out in showing how the reading skill takes an essential part in EFL classroom. Reading skill, with proficiency in it, is one of the most lifetime useful skills either within or beyond classroom setting since it is assumed to support other skills. For instance, the students will get difficulty in expressing their ideas through speaking and producing the outcomes in writing such as journal, article, etc., if they do not have any background knowledge that can be gotten by reading. To enhance students' reading ability and strategy, various approaches are applied in reading class. In other words, many teachers come in attempt on preparing good method and strategy to achieve this goal. Nevertheless, many teachers right now just focuses on how to improve students' learning by applying various strategies of learning without concerning on teaching materials as the main way to connect the students and new knowledge. In this case, choosing inappropriate teaching materials will get students difficulty in comprehending the text. Yet, in our education today, Most of EFL class, through the fourth class until the twelfth class, is focused in non-authentic materials.

Here, the teaching materials are selected without take note of the suitability of levels and topics desired by the students. the teacher tends to prepare the teaching material gotten by the commercial textbook, instead of focusing on finding out whether the teaching materials have represented the state of real communication or not. As the result, when they are at university level, they are found difficulty to develop their reading proficiency. Because of these problems, it demands the teacher to find another source of reading to teach reading to students that it may attract their interest to read.

One of the sources of reading that is appropriate to apply in teaching reading subject is authentic material. Authentic material leads the reader to communicate effectively since it makes students to read according to their interest and to get what has been expressed by the writer. On the other hand, the students read not only to master the structure of the text or to practice their comprehension by answering the question at the time finishing the text, but more then to dip into the real-world situation in terms of target language.

Some previous research about authentic reading material has been employed by some researchers but the strategy of using authentic reading material is still largely unexplored. Therefore, the research into the effect of authentic reading material for enhancing language skill is still limited. For this reason, this research will provide some investigations to know is there any significant effect of authentic material on students' reading comprehension.

\section{Research Question}

To what extent does authentic material enhance students' reading comprehension?

\section{LITERATURE REVIEW}

\subsection{Reading Comprehension}

According to Goodman in Cahyono (2009), reading is as essential interaction between language and thought in which the writer encodes his thoughts as language and the reader decodes the language into thought. Therefore, reading consists of two related processes: word recognition and comprehension. Word recognition refers to the process of perceiving how written symbols correspond to one's spoken language. Comprehension is the process of making sense of word, sentence and connected texts. 
Reading comprehensions defined as the level of understanding of writing. The reading comprehension focused on the ability to draw the meaning from certain writing. According to Buehl (2001) in the past, reading comprehension was described more as a skill than as an active mental process. Reading is understood as the skill of recognizing letters, words, which let to the ability to connect words into sentences, sentences into paragraph and paragraph into longer discourse that represented various themes or ideas. However, the key concept of comprehension is that a reader constructs meaning from texts rather than merely reproducing the words on the page. Meaning is something that is actively created rather than passively received.

\subsection{Authentic Materials}

The material used in teaching English, especially for reading is categorized into two, those are authentic and non-authentic material. Gilmore (2007) contended that authentic texts convey a message produced by a real author to a real audience, such as newspapers, letters, and books and he also believed that authentic texts can promote the interest among the learners. Here are the definition of both kind of materials. According to Lindsay and Knight (2006) there are two basic types of the text-authentic and non-authentic. Examples of authentic text are newspaper article, website pages, email, and packaging and label and so on. Non- authentic texts are written especially for learners using imaginary context and simplified vocabulary and sentence construction, for example, a reading text in an elementary course book, and a reader for young learners.

The statement of Lindsay and Knight above means that there are two kinds of text namely authentic and non- authentic texts. The non -authentic texts are the reading material which written for the learners by using simplified vocabulary and sentence construction. It usually found in course book and lesson book. Otherwise, the authentic texts are written not for learners, using simplified vocabulary, and sentence construction. The examples of authentic material are article in newspaper, magazines, email, etc.

According to Wallace as quoted by Wicaksono in Cahyono (2009) authentic texts defined as real life texts, not written for pedagogic purposes. This definition is virtually the same with the preceding; it means that authentic texts are real text that is not intended for educational purpose. However, Harmer (2001) gives other explanation about it. He stated that when we ask students to read, the success of the activity will often depend on the level of the text we are asking to them to work with. Ideally, we would like students to read authentic texts- in other words, texts that are not written especially for language learners, but which are intended for any competent user of the language.

Those explanations mean that the authentic materials are not written for the language learner. It is for the competent user of language or even for the native speaker.

Widdowson's in Martinez (2002) differentiates the terms authentic and genuine material. Authentic would be material designed for native speakers of English used in the classroom in a way similar to the one it was designed for. For example, a radio news report brought into the class so students discuss the report on pollution in the city where learners live. Most of the time, though, this material is used in a genuine way, in other words, not in the way it was intended, but in a somewhat artificial way. For example, news article where the paragraphs are cut up and jumbled so students have to put them back together in the correct order. 
There are some differences of the characteristics of authentic and non-authentic material. In authentic materials, language data produced for real life communication purposes. They may contain false starts, and incomplete sentences. They are useful for improving the communicative aspects of the language. In the other hand, the nonauthentic materials are specially designed for learning purposes. The language used in them is artificial. They contain well-formed sentences all the time so; it is useful for teaching grammar.

In conclusion, the authentic materials or authentic texts are texts that are not produced for either the educational purpose or the language but for the competent user of language. It usually intended for real life communication purpose.

\section{METHODS}

\subsection{Research Design}

This study used quasi-experimental design that consists of experimental class and control class. Sugiyono (2016:116) define quasi-experimental design as the design that would provide as much control as possible under the existing situation and it is used when true experimental design is not feasible. The experimental group was teach by the first researcher and receive treatment that is using authentic material and the control group was teach by the second researcher and using textbook.

\subsection{Research Participants}

This research conducted at Sembilan belas November University and Lakidende University and there were two classes from involved in. There were 30 students at Sembilan belas November and 30 Students at Lakidende University whose program Reading 3 subject. The reason of choosing the third semester students are as they have had many experiences in reading text and ideally the students in this semester have already known the nature of authentic materials.

\subsection{Research Instruments}

In this study, the reading comprehension test consists of multiple choice 30 items after pilot study. The reading test is the same in use on pre-test and post-test, only one answer is correct for multiple choices, and one point is given to the correct answer and zero for the false one.

\subsection{Data Collection Procedures}

\subsubsection{Pre-test}

The pre-test which was conduct to both experimental and control group is carried out to find out students' prior knowledge in reading comprehension performance before receiving treatment.

\subsubsection{The Treatment}

Following the pre-test, the students in experimental and control group received difference treatment. The authentic material was implemented to the experimental class. Whereas in control class was using textbook.

\subsubsection{Post Test}

Next, the post-test was given to the students after receiving four meetings of treatment. Then, the result of pre-test and post-test both of two different groups: experimental and control group are compare to examine whether there is significant effect on students' reading performance. 


\subsection{Technique of Analyzing Data}

This research employed statistical data analysis procedures: descriptive statistics and independent samples t test. The Statistical Package for the Social Science (SPSS, version 24.0) was used to analyze the data.

\section{DISCUSSION}

\section{a. Comparison of Pre-Test and Post-Test score in Experimental Class and Control Class}

The characteristics of students' score of the third year students of Lakidende University and Sembilan belas November University before and applying both authentic reading material and non-authentic can be seen on the table 1.1.

Table 1.1 The summary of the descriptive statistic from students' pre test and post test in experimental class and control class

\begin{tabular}{|l|c|c|c|c|c|c|}
\hline \multirow{2}{*}{$\begin{array}{c}\text { Students' } \\
\text { Score }\end{array}$} & \multicolumn{2}{|c|}{ Experimental Class } & \multirow{2}{*}{ Gain } & \multicolumn{2}{c|}{ Control Class } & Gain \\
\cline { 2 - 3 } & Pre test & Post Test & Score & Pre & Post & Score \\
\hline Mean & 57.73 & 88.53 & 30.42 & 57.47 & 78.93 & 20.89 \\
\hline Std. deviation & 10.799 & 9.951 & -0.955 & 9.066 & 9.962 & 0.805 \\
\hline Minimum & 28 & 60 & 31.72 & 34 & 48 & 13.66 \\
\hline Maximum & 76 & 100 & 23.24 & 76 & 92 & 15.24 \\
\hline
\end{tabular}

Based on the description of students' score above, it can be conluded that the students' score on post test in experimental is higher or better than the students' score on pre test, in which the mean score on pre test is 57.73 while the mean score on post test is 88.53 . It means that the increasing of students' average score from pre test to post test is 30.8. While, in the control class, the students' score on post test in control class is higher than the students' score on pre test, in which the mean score on pre test is 57.47. While the mean score on post test is 78.93 . It means that the increasing of students' average score from pre test to post test is 21.46.

For the result of students' gain score in experimental class is 30.42 and for control class is 20.89 it is proves the students' reading ability who taught by using authentic reading material has significant improving. This result also proves that the gain score of the students in experimental class is higher than the gain score of the students in control class. Hence, the students' reading ability in experimental class that is taught by authentic reading material has more significant effect.

\section{b. The Result of Classical Assumption Test}

Before the hypothesis testing was applied, a classical assumption test should be done first. The present study used parametric statistics namely Independent Sample Test analysis. However, this analysis only could be used if the classical assumption test had been fulfilled. It included test of normality.

\section{The Result of Normality Test}

The test of normality was aimed to assess whether the data were normally distributed. In this present study, Shapiro-Wilk test was employed to examine whether the data are normally distributed or not. Theoretically, if the value of $\mathrm{p}$ was more than $\alpha 0.05$ or $(p>0.05)$, it meant that the data were normally distributed. However, if it was less than $\alpha 0.05$ or $(\mathrm{p}<0.05)$, it meant that the data significantly deviated from a normal distribution. 
Table 1.2 The Result of Normality Test of students' authentic reading material

Tests of Normality

\begin{tabular}{|l|l|r|r|r|r|r|r|}
\hline & & \multicolumn{3}{|c|}{ Kolmogorov-Smirnova } & \multicolumn{3}{|c|}{ Shapiro-Wilk } \\
\cline { 3 - 8 } & \multicolumn{1}{|c|}{ Group } & \multicolumn{1}{c|}{ Statistic } & \multicolumn{1}{c|}{$\mathrm{df}$} & \multicolumn{1}{c|}{ Sig. } & Statistic & \multicolumn{1}{c|}{$\mathrm{df}$} & \multicolumn{1}{c|}{ Sig. } \\
\hline \multirow{2}{*}{ Ngain } & Experiment & .102 & 30 & $.200^{*}$ & .970 & 30 & .549 \\
& Control & .136 & 30 & .167 & .963 & 30 & .377 \\
\hline
\end{tabular}

*. This is a lower bound of the true significance.

a. Lilliefors Significance Correction

Table above displays the normality of gain in experimental and control class. The result of normality for experimental class is 0.549 ( Pvalue $>0.05$ ), while the result of normality control class is 0.377 ( Pvalue >0.05) which is higher than 0.05 . it can be inferred that all the data both pre test and post test are normally distribute. It meant that it was acceptable to be analyzed through parametric statistic test in form of Independent Sampel Test analysis in SPSS 24 for windows.

\section{c. The Result of hypothesis testing}

Based on the result of the normality test previously; there was no assumption that was violated. On the other hands, it meant that it was acceptable to be analyzed through parametric statistic test in form of Independent Sampel Test analysis in SPSS 24 for windows.

\section{To what extent does authentic material enhance students' reading comprehension}

The hypothesis in this study was that "There was a significant effect of using authentic reading material on students' reading comprehension or not". Based on the result of Independent Sampel Test analysis in SPSS 24, it indicated that there was a significant effect of using authentic reading material on students' reading comprehension as can be seen on table below:

Table 1.3 The Result of Independent Sampel Test Analysis

\begin{tabular}{|c|c|c|c|c|c|c|c|c|c|}
\hline \multicolumn{10}{|c|}{ Independent Samples Test } \\
\hline & \multicolumn{2}{|c|}{$\begin{array}{c}\text { Levene's Test for } \\
\text { Equality of } \\
\text { Variances }\end{array}$} & \multicolumn{7}{|c|}{ t-test for Equality of Means } \\
\hline & \multirow[b]{2}{*}{$\mathrm{F}$} & \multirow[b]{2}{*}{ Sig. } & \multirow[b]{2}{*}{$\mathrm{t}$} & \multirow[b]{2}{*}{ df } & \multirow{2}{*}{$\begin{array}{l}\text { Sig. (2- } \\
\text { tailed) }\end{array}$} & \multirow{2}{*}{$\begin{array}{c}\text { Mean } \\
\text { Differenc } \\
\mathrm{e} \\
\end{array}$} & \multirow{2}{*}{\begin{tabular}{|c|} 
Std. \\
Error \\
Differenc \\
$\mathrm{e}$ \\
\end{tabular}} & \multicolumn{2}{|c|}{$\begin{array}{c}95 \% \text { Confidence } \\
\text { Interval of the } \\
\text { Difference }\end{array}$} \\
\hline & & & & & & & & Lower & Upper \\
\hline $\begin{array}{ll}\text { Nga } & \text { Equal variances } \\
\text { in } & \text { assumed } \\
& \text { Equal variances } \\
& \text { not assumed }\end{array}$ & 10.100 & .002 & $\begin{array}{l}3.550 \\
3.550\end{array}$ & $\begin{array}{r}58 \\
44.89 \\
7\end{array}$ & $\begin{array}{l}.001 \\
.001\end{array}$ & $\begin{array}{l}9.333 \\
9.333\end{array}$ & $\begin{array}{l}2.629 \\
2.629\end{array}$ & $\begin{array}{l}4.070 \\
4.037\end{array}$ & $\begin{array}{r}14.597 \\
14.629\end{array}$ \\
\hline
\end{tabular}


Table above shows that statistical analysis of independent Sample t-test has been conducted to compare result for experiment and control class in their reading comprehension. The result shows that authentic reading material has a noteworthy impact on students' reading comprehension. The probability value ( $p$ value) is less than the level of significant which $p$ value is $0.001<0.05$ (alpha value). Means, there is difference mean score on experimental and control class class.

\section{CONCLUSION}

The present study attempted to answer a question concerned to what extent does authentic material enhances students' reading comprehension. To answer this research question, the results obtained from the pre-test and the post-test of the authentic group was compared. Results showed that the means of the authentic group in the post-test was higher than the pre-test. In other words, teaching with authentic reading material was improved in terms of reading comprehension. Besides that, The difference mean score on experimental and control class class can be seen by the result of independent sample test formula, where Sig. (2-tailed) of post-test in both experiment and control class are 0.001. It means that $\mathrm{p}<0.05, \mathrm{p}=0.001$. so it can be concluded that the null hypothesis (H_0) was rejected and the alternative hypothesis (H_1) was accepted. Considering the results obtained from the analysis of the related data, it can be argued that the authentic materials used in teaching reading were effective in the experimental group. The authentic reading comprehension passages were interesting for the language learners. After reading authentic texts, students became more motivated to read about their own favorite topics and new things.

\section{REFERENCES}

Buehl, Doug. 2001.Classroom Strategies For Interactive Learning.Delaware: International Reading Association ,Inc

Cahyono. B.Y.2009. Teaching English with Insights from Linguistics. Malang: State University of Malang Press.

Gilmore, A. (2007). Authentic materials and authenticity in foreign language learning. Language Teaching, Vol. 40 No. 2, p. 97-118 4. Harmer, Jeremy. 2001. The practice of English language teaching. Longman. United Kingdom.

Lindsay,Cora, and Paul Knight.2006.Learning and Teaching English: A Course for Teachers. Oxford: Oxford University Press.

Harmer, Jeremy. 2001. The practice of English language teaching. Longman. United Kingdom.

Martinez, G \& Alejandro, M.A. 2002. Authentic Materials: An Overview. Mexico City.Retrivied on January 27th, 2015 from http://marliajauhari.blogspot.co. id/2013/04/normal-0-false-false-false-en-us-X-none.html

Sugiyono. 2016. MetodePenelitian Pendidikan PendekatanKuantitatif, Kualitatif, dan R\&D. Alfabeta Bandung. 